\title{
Fatty acid composition, antioxidant and antibacterial properties of the microwave aqueous extract of three varieties of Labisia pumila Benth
}

\author{
Ehsan Karimi ${ }^{1 *}$, Hawa ZE Jaafar ${ }^{1 *}$, Ali Ghasemzadeh ${ }^{1}$ and Mahdi Ebrahimi ${ }^{2}$
}

\begin{abstract}
Background: The present study was conducted in order to evaluate the fatty acid profile, anti-oxidant and antibacterial activities from the microwave aqueous extract of the leaves of three different varieties of Labisia pumila Benth.

Results: The chemical analysis of the extract showed that fatty acids (palmitic, palmitoleic, stearic, oleic, linoleic and a-linolenic) acid as the main components in three varieties of L. pumila leaves. Furthermore, the obtained results of the anti-oxidant revealed that $L$. pumila var. alata contained higher anti-oxidative activities compared to var. pumila and var. lanceolata. However, these values were lower than the tested anti-oxidant standards. On the other hand, the aqueous leaf extracts in all three varieties of $L$. pumila were also found to inhibit a variable degree of antibacterial activities against eight bacteria (four Gram-positive and four Gram-negative bacteria).
\end{abstract}

Conclusions: In this study, it was observed the leaves of three varieties of L. pumila exhibited variable patterns of fatty acids and the microwave aqueous extraction possess anti-oxidant and anti-bacterial activities.

Keywords: Fatty acid composition, Microwave aqueous extraction, Anti-oxidant activities, Anti-bacterial activities

\section{Background}

Anti-oxidant is a chemical substance extremely useful due to prevent or delay the formation of free radicals and lipid peroxidation in the animals and human bodies, two main causes of animals and human disease and aging [1]. It helps us ward off many kinds of disease related to lungs, kidneys, heart, cardiovascular system, muscle and brain, and it helps to retard the aging process [2].

Fatty acids are molecules typically found attached to other compounds such as sugars, glycerol or phosphate head groups to form lipids. Lipids are necessary components of cell structures, for example for cell membranes, which are main components' of phospholipids, and energy stores that are often composed of triglycerides.

\footnotetext{
*Correspondence: Ehsan_b_karimi@yahoo.com; hawazej@gmail.com 'Department of Crop Science, Faculty of Agriculture, Universiti Putra Malaysia, 43400 Serdang, Selangor, Malaysia

Full list of author information is available at the end of the article
}

Fatty acids are released from lipids, typically by the action of enzymes, to become free fatty acids, which have vast and potent biological activities [3]. The biological activities of free fatty acids have roles in host defenses against potential opportunistic or pathogenic microorganisms. An important aspect of this is growth inhibition or the quick destroying of bacteria. several studies for understanding the mechanism of the anti-bacterial effects of different fatty acids from a wide range of biological sources such as algae, animals and plants have been done by several researchers [3,4]. Indeed, fatty acids are normally identified as the active ingredients in ethnic and herbal medicines [5,6]. Tropical and subtropical plants are perceived to produce a large variety of phytochemicals or secondary metabolites and possess a wide range of cancer preventive. Most of these secondary metabolites are isolatedfrom wild or cultivated plants because their chemical synthesis is either extremely difficult or economically not available due to their highly 
complex structures and specific stereo-chemical requirements of the compounds [7]. Labisia pumila Benth. (Myrsinaceae) is a wild forest herb and reported contain several bioactive compounds, which include phenolics, triterpenoids (e. g. phytosterols, saponins, sapogenins, non-steroidal and triterpenoids) and peptides [8]. The chemistry of many species of this family is little known of traditional uses to treat various ailments [9]. This study was aimed to investigate the total phenol and flavonoid content, fatty acid profiling, anti-oxidant activity and anti-bacterial properties of aqueous extracts of three varieties of medicinal plant, $L$. pumila Benth. obtained from microwave extraction.

\section{Results}

Total phenolics (TP) and flavonoids (TF) compounds

The total phenolic and flavonoid contents results from the study showed that in general the leaves of L. pumila var. pumila had higher total flavonoids content than var. alata and var. lanceolata But, the aqueous leaf extract of $L$. pumila var. alata contained higher total phenolics than var. pumila and var. lanceolata (Table 1). Total phenolics and flavonoids content of leaves in all three varieties of $L$. pumila were significantly different with each other.

\section{Analysis of fatty acid profiling}

The fatty acid composition of the L. pumila leaves extract in different varieties was presented in Table 2. The most abundant fatty acid present in the aqueous extract of Labisia was (C16:0 and C18:2n-6), which accounted for approximately $24.58-28.21 \%$ and $24.49-28.84 \%$ of total identified fatty acids. The palmitic acid (C16:0) was highest in alata variety when compared to other varieties. The proportion of leaves extract fatty acids having 18 carbons was quite consistent across the three varieties, averaging between 69.51 to $71.53 \%$ (Table 2). Mean concentrations of C18:0, C18:1n-9, C18:2n-6, and C18:3n-3 were $4.36,18.73,27.52$, and $21.20 \%$, respectively. On the other hand, C18:3n-3 in Lanceolata variety showed a significantly higher amount compared to other varieties. The varieties showed significant $(P<0.05)$ effects on C18:3n-3 in the Labisia pumila leaves.

Table 1 Total phenolics and flavonoids content of the leaves aqueous extract of three varieties of Labisia pumila Benth (Mean $\pm \mathrm{SEM}$; $\mathbf{n}=\mathbf{3}$ )

\begin{tabular}{lcc}
\hline Leaf extract & Phenolic content $^{\mathbf{1}}$ & Flavonoid content $^{\mathbf{2}}$ \\
\hline Alata & $3.07 \pm 0.28^{\mathrm{a}}$ & $1.39 \pm 0.11^{\mathrm{b}}$ \\
Pumila & $2.96 \pm 0.21^{\mathrm{b}}$ & $1.94 \pm 0.15^{\mathrm{a}}$ \\
Lanceolata & $2.78 \pm 0.24^{\mathrm{c}}$ & $1.35 \pm 0.13^{\mathrm{c}}$ \\
\hline
\end{tabular}

${ }^{1} \mathrm{mg}$ gallic acid equivalent/g DW; ${ }^{2} \mathrm{mg}$ rutin equivalent/g DW; Results are means of three replicates \pm standard error. Means with the different letters are significantly different from each other at $P<0.05$.
Table 2 Fatty acid profile of microwave aqueous extract of three varieties of Labisia pumila Benth (Mean \pm SEM; $\mathbf{n}=\mathbf{3})$

\begin{tabular}{lrrr}
\hline & \multicolumn{1}{c}{ Alata } & \multicolumn{1}{c}{ Pumila } & Lanceolata \\
\hline C16:0 & $28.21 \pm 1.31^{\mathrm{a}}$ & $27.05 \pm 3.50^{\mathrm{ab}}$ & $24.58 \pm 0.54^{\mathrm{b}}$ \\
C16:1 & $2.29 \pm 1.02$ & $1.43 \pm 0.26$ & $1.05 \pm 0.29$ \\
C18:0 & $4.67 \pm 0.34$ & $4.64 \pm 0.38$ & $3.76 \pm 0.57$ \\
C18:1 & $18.83 \pm 0.08$ & $19.67 \pm 0.85$ & $17.68 \pm 0.42$ \\
C18:2 n-6 & $24.99 \pm 0.80$ & $28.73 \pm 2.44$ & $28.84 \pm 0.20$ \\
C18:3 n-3 & $21.01 \pm 2.29^{\mathrm{ab}}$ & $18.50 \pm 0.86^{\mathrm{b}}$ & $24.08 \pm 0.21^{\mathrm{a}}$ \\
${ }^{1}$ Total saturated & $32.88 \pm 1.51$ & $31.68 \pm 3.88$ & $28.34 \pm 0.73$ \\
${ }^{2}$ Total monoenes & $21.12 \pm 0.98$ & $21.09 \pm 0.61$ & $18.73 \pm 0.53$ \\
${ }^{3}$ Total PUFA n-3 & $21.01 \pm 2.29^{\mathrm{ab}}$ & $18.50 \pm 0.86^{\mathrm{b}}$ & $24.08 \pm 0.21^{\mathrm{a}}$ \\
${ }^{4}$ Total PUFA n-6 & $24.99 \pm 0.80$ & $28.73 \pm 2.44$ & $28.84 \pm 0.20$ \\
${ }^{5}$ Total polyunsaturated & $46.00 \pm 2.81^{\mathrm{b}}$ & $47.23 \pm 3.28^{\mathrm{b}}$ & $52.92 \pm 4.25^{\mathrm{a}}$ \\
PUFA n-6 : PUFA n-3 & $1.19 \pm 0.15$ & $1.55 \pm 0.06$ & $1.20 \pm 0.01$ \\
Polyunsaturated: & $1.41 \pm 0.13$ & $1.57 \pm 0.32$ & $1.87 \pm 0.05$ \\
saturated & & & \\
\hline
\end{tabular}

${ }^{1}$ Total Saturated $=$ sum of $\mathrm{C} 16: 0+\mathrm{C} 18: 0$.

${ }^{2}$ Total Monoenes $=$ sum of $C 16: 1+C 18: 1 n-9$.

${ }^{3}$ Total $n-3 P U F A=$ sum of $C 18: 3 n-3$.

${ }^{4}$ Total $n-6 P U F A=$ sum of $C 18: 2 n-6$.

${ }^{5}$ Total Polyunsaturated fatty acid $=\mathrm{C} 18: 2 n-6+\mathrm{C} 18: 3 n-3$.

Values with different superscripts between rows differ significantly at $P<0.05$.

\section{Anti-oxidant activity (ABTS and NO scavenging)}

Figures 1 and 2 show the anti-oxidant activities of aqueous extracts obtained from Labisia pumila var. alata, pumila and lanceolata in the reactions with ABTS radical and nitric oxide respectively. The obtained results revealed that the L. pumila var. alata contained higher antioxidative activities compared to var. pumila and lanceolata. However, these values were lower than the tested anti-oxidant standards. The aqueous extracts inhibited the free radicals in a dose dependent manner. The $\mathrm{IC}_{50}$ concentrations (Table 3 ) showed significant $(P<0.05)$ differences in ABTS and NO scavenging activity among samples, where $L$. pumila var. alata showed the lowest value, followed by pumila and lanceolata.

\section{Anti-bacterial activity determination}

The result obtained from anti bacterial assays is presented in Table 4 at concentration of $300 \mu \mathrm{g} / \mathrm{disc}$. The extracts of leaves in all three varieties of L. pumila were also found to inhibit a variable degree of antibacterial activities against eight bacteria (four Gram-positive and four Gram-negative bacteria). The inhibition from those extracts showed low inhibition compared to kanamycin, as the positive control. Kanamycin as a standard antibiotic showed high inhibition zones at a concentration of $1 \mu \mathrm{g} /$ disc. As a comparison among three varieties, $L$. pumila var. of pumila exhibited higher inhibition zone with diameters ranging from $0.37-0.75 \mathrm{~cm}$ against $(P$. 


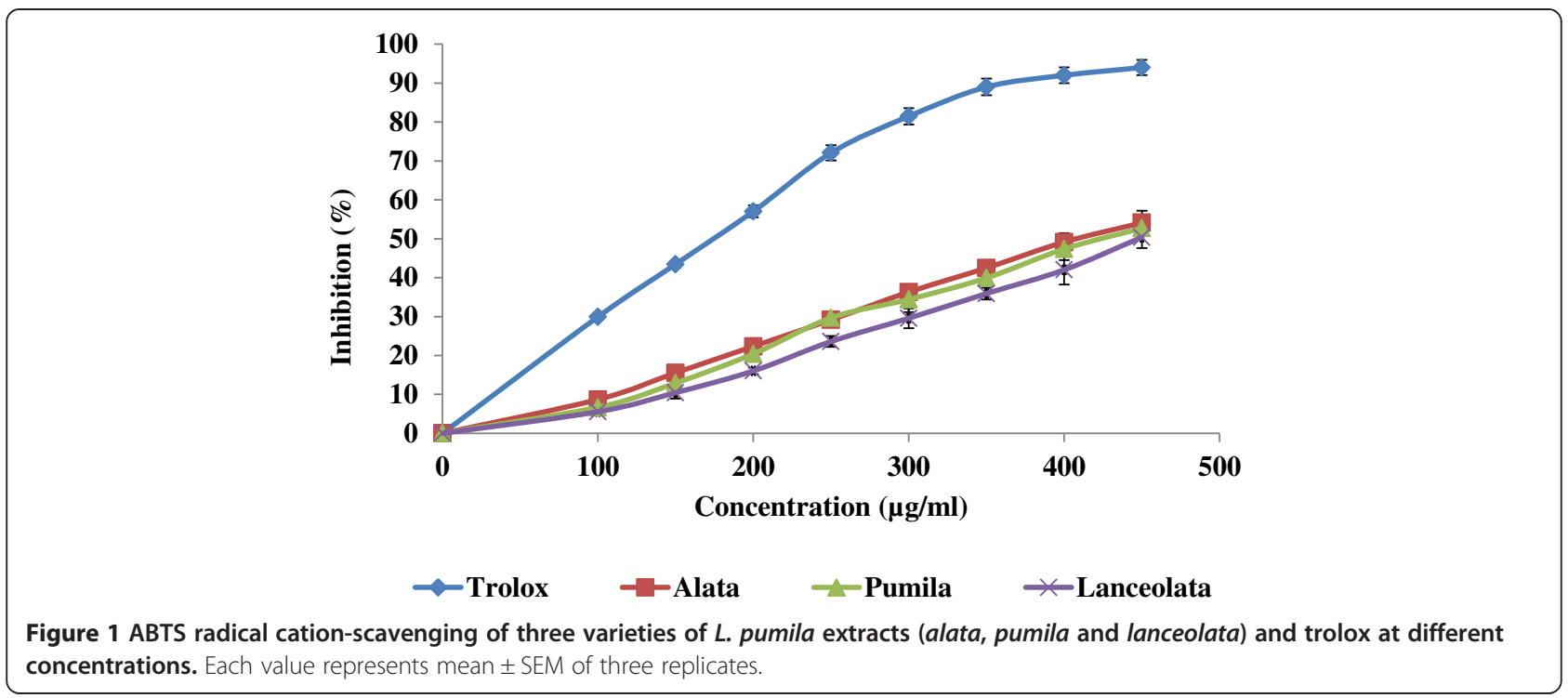

aeruginosa and B. subitilis), compared to L. pumila var. alata and lanceolata. Meanwhile, L. pumila var. alata exhibited higher inhibition zone with diameters ranging from $0.4-1.03 \mathrm{~cm}$ against (Pseudomonas aeruginosa and Escherichia coli) compared to L. pumila var. pumila and var. lanceolata. From the results, it can be concluded that Gram-positive bacteria were found to be more sensitive against the extracts than Gram-negative bacteria.

\section{Discussion}

Natural phytochemicals including flavonoid and phenolic compounds and fatty acids are major bioactive compounds known to be beneficial against many diseases and have been reported to possess a wide range of biological effects like anti-oxidant and antibacterial activities [10]. Phenolic and flavonoid compounds, important phytochemicals, are present in vegetables, fruits and cereal grain. These secondary metabolites are natural anti-oxidants that have multiple biological effects and play an important role in the defense against cardiovascular disease, aging and cancer [11]. The results of the present study showed that aqueous leaves extract obtained from microwave extraction have anti-oxidant potentials and antibacterial properties. From the results it can be concluded that L. pumila var. lanceolata possess consistently the lowest values of total phenolics and total flavonoids contents, anti-oxidant and antibacterial activities

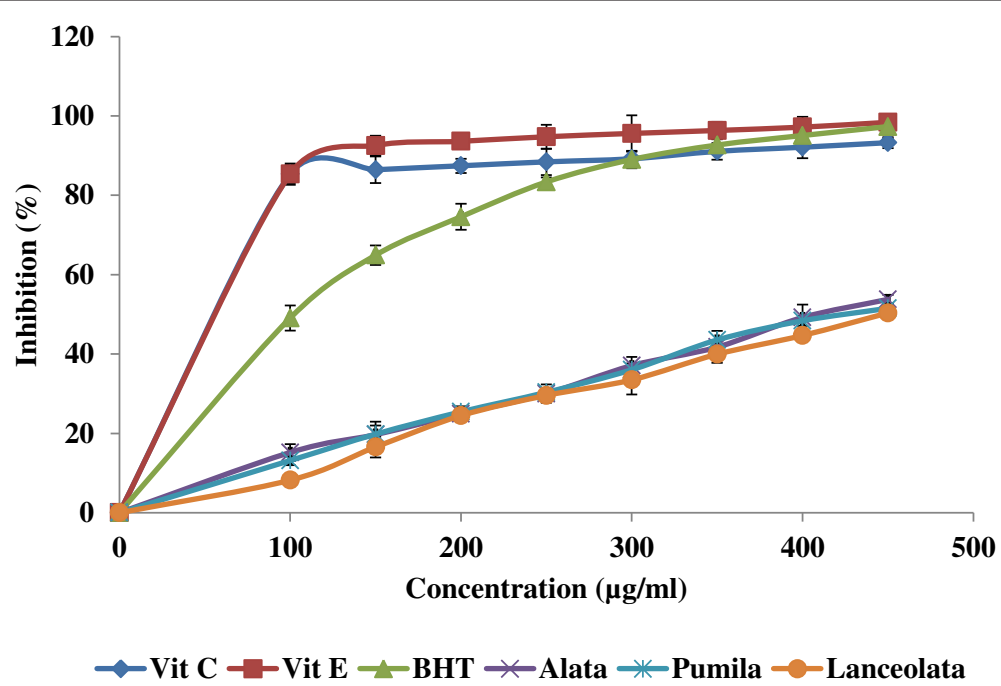

Figure 2 Nitric oxide scavenging activity of three varieties of $L$. pumila extracts (alata, pumila and lanceolata) and vitamins at different concentrations. Each value represents mean \pm SEM of three replicates. 
Table 3 The IC50 values of extracts and standards in $A B T S$ and nitric oxide scavenging activities (Mean \pm SEM; $\mathbf{n}=\mathbf{3}$ )

\begin{tabular}{lcc}
\hline Samples & \multicolumn{2}{c}{$\mathbf{I C}_{\mathbf{5 0}}(\boldsymbol{\mu \mathbf { g }} / \mathbf{m L})$} \\
\cline { 2 - 3 } & $\begin{array}{c}\text { ABTS radical } \\
\text { scavenging activity }\end{array}$ & $\begin{array}{c}\text { NO } \\
\text { scavenging activity }\end{array}$ \\
\hline L. pumila var. alata & $399.02 \pm 1.12^{\mathrm{c}}$ & $411.53 \pm 1.65^{\mathrm{c}}$ \\
L. pumila var. pumila & $424.57 \pm 1.87^{\mathrm{b}}$ & $425.87 \pm 1.52^{\mathrm{b}}$ \\
L. pumila var. lanceolata & $448.20 \pm 2.15^{\mathrm{a}}$ & $449.29 \pm 2.03^{\mathrm{a}}$ \\
Vitamin C & - & $59.91 \pm 3.42^{\mathrm{f}}$ \\
Vitamin E & - & $62.6 \pm 2.62^{\mathrm{e}}$ \\
BHT & - & $118.73 \pm 1.73^{\mathrm{d}}$ \\
Trolox & \multicolumn{2}{|}{$187.47 \pm 1.01^{\mathrm{d}}$} \\
\hline
\end{tabular}

Means in the same column with the different superscripts are significantly different at $P<0.05$.

when compared to the other two varieties, which are popularly researched on. This is maybe due to the variation of secondary metabolite and fatty acid content present in the extracts. For examples apigenin [12] naringin and naringenin [13], quercetin, 3-O-methylquercetin and various quercetin glycosides [13], gallic acid and pyrogallol [14] were identified to possess high anti-oxidant and antibacterial activities. It was found that the aqueous extract of Labisia pumila leaves contains fatty acids (palmitic, palmitoleic, stearic, oleic, linoleic and $\alpha$-linolenic) with the latter as main component. This is in the first report of Labisia pumila leaves fatty acid profiles. The fatty acids are said to exhibit antibacterial activity [3]. Fatty acids can act as anionic surfactants and have antibacterial and antifungal properties at low $\mathrm{pH}$ [15]. In addition to being selective against Gram-positive organisms [16] by targeting the structure and function of bacterial cell walls and membranes. These components may be the contributing

Table 4 Inhibition zones of aqueous leaf extracts of three varieties of Labisia pumila against pathogenic bacteria at concentration of $300 \mu \mathrm{g} /$ disc (Mean \pm SEM; $\mathbf{n}=\mathbf{3}$ )

\begin{tabular}{|c|c|c|c|c|}
\hline \multirow[t]{3}{*}{ Sample } & \multicolumn{4}{|c|}{ Inhibition zone $(\mathrm{cm})$} \\
\hline & \multicolumn{4}{|c|}{ Gram-positive bacteria } \\
\hline & B. subitilis & S. aureus & B. cereus & M. luteus \\
\hline Alata & $0.72 \pm 0.11^{b}$ & $0.65 \pm 0.15^{c}$ & $0.75 \pm 0.13^{b}$ & $0.55 \pm 0.06^{b}$ \\
\hline Pumila & $0.75 \pm 0.23^{b}$ & $0.70 \pm 0.13^{b}$ & $0.73 \pm 0.25^{b}$ & $0.50 \pm 0.17^{b}$ \\
\hline Lanceolata & $0.65 \pm 0.46^{c}$ & $0.55 \pm 0.07^{d}$ & $0.60 \pm 0.16^{c}$ & $0.40 \pm 0.22^{c}$ \\
\hline \multirow[t]{3}{*}{ Kanamycin } & $1.15 \pm 0.05^{\mathrm{a}}$ & $0.95 \pm 0.03^{\mathrm{a}}$ & $1.02 \pm 0.09^{a}$ & $0.91 \pm 0.05^{\mathrm{a}}$ \\
\hline & \multicolumn{4}{|c|}{ Gram-negative bacteria } \\
\hline & E. coli & P. aeruginosa & E. aerogenes & K. pneumonie \\
\hline Alata & $0.90 \pm 0.15^{b}$ & $0.40 \pm 0.23^{b}$ & $0.63 \pm 0.07^{b}$ & $0.60 \pm 0.09^{b c}$ \\
\hline Pumila & $0.85 \pm 0.09^{c}$ & $0.37 \pm 0.17^{\mathrm{bc}}$ & $0.45 \pm 0.15^{c}$ & $0.65 \pm 0.25^{b}$ \\
\hline Lanceolata & $0.78 \pm 0.12^{d}$ & $0.30 \pm 0.11^{c}$ & $0.40 \pm 0.19^{c d}$ & $0.55 \pm 0.33^{c}$ \\
\hline Kanamycin & $1.30 \pm 0.03^{\mathrm{a}}$ & $0.92 \pm 0.05^{\mathrm{a}}$ & $1.05 \pm 0.05^{\mathrm{a}}$ & $1.20 \pm 0.11^{a}$ \\
\hline
\end{tabular}

Means with different superscripts within column are significantly different $(P<0.05)$. factors to the effect demonstrated by the aqueous extract of Labisia pumila. The similar studies showed thatpalmitic, stearic, oleic, linoleic and linolenic acids are well known to have antibacterial activities [5]. Our study undoubtedly confirms that the leaves extract of Labisia pumila contains a higher relative percentage of the abovementioned fatty acids that has potential anti-oxidant and anti-bacterial principle for clinical application.

\section{Conclusions}

Throughout history, natural products have afforded a rich source of compounds that have found many applications in the fields of medicine, pharmacy and biology [17]. The present study elucidates the potentials effects of the antioxidant and antibacterial properties of the Labisia Pumila leaves obtained from the microwave extraction. These antioxidant and antimicrobial activities of L. pumila could be attributed to various fatty acids and phytochemical constituents (flavonoid, phenolic) present in the aqueous leaves crude extract. The leaf is the main source of antimicrobial and anti-oxidants, which have shown to posses radical scavenging activities and reducing potential.

\section{Methods}

\section{Chemicals}

Methanol, hydrochloric acid, Folin-Ciocalteu reagent, sodium carbonate, aluminium chloride, sodium hydroxide, ascorbic acid, alpha-tocopherol, butylatedhydroxytoluene (BHT), dimetylsulfoxide (DMSO), $\mathrm{KOH}$ and trifluoride $\left(\mathrm{BF}_{3}\right)$ were purchased from Fisher Scientifics, USA. The other chemicals used in this study were bought from Merck.

\section{Plant material}

Seedlings of Labisia pumila varieties alata, pumila, and lancelota were, respectively, collected from places of origin at Sungkai, Perak; Hulu Langat, Selangor, and Kota Tinggi, Johore, and raised under similar glasshouse condition for 18 months before use in the study. The GPS location details were $3^{\circ} 0^{\prime} 35.27 " \mathrm{~N}$ latitude and $101^{\circ}$ 4219.38"E longitude. Healthy and uniform seedlings in term of leaf numbers were selected from the three varieties. The leaves of three varieties of Labisa pumila Benth. were cleaned, separated, and freeze dried for further analysis.

\section{Microwave Assisted Extraction (MAE)}

MAE was performed on microwave apparatus using a closed vessel system with pressure (ETHOS ${ }^{\circledR} \mathrm{T}$ Microwave digestion/extraction system, Milestone Co., Italy) based on the method described by Xiao et al. [18] with some modification. One gram of leaf part of three varieties of Labisia pumila was weighed using a clean aluminum container, then transferred into the vessel of the Ethos E Microwave 
Extraction System and extracted with $30 \mathrm{ml}$ of water as solvent for $2 \mathrm{~min}(\mathrm{p}=750 \mathrm{w})$. The extraction temperature was applied to $80^{\circ} \mathrm{C}$. After extraction, the vessels were allowed to cool at room temperature before opening. Then the extracts were filtered and stored in refrigerator.

\section{Total phenolics determination}

For total phenol determination, briefly $0.5 \mathrm{ml}$ of each methanolic extract, $2 \mathrm{ml}$ of $7.5 \%$ sodium carbonate and $2.5 \mathrm{ml}$ Folin-Ciocalteu reagent were mixed together. The mixture was then vortex and incubated for $90 \mathrm{~min}$ at room temperature [19]. The absorbance was read using a spectrophotometer (Novaspec II Visiblespectro, Japan) at $765 \mathrm{NM}$. The total phenol results were expressed as mg gallic acid equivalents (GAE)/g dry weight (DW).

\section{Total flavonoids determination}

For total flavonoid compounds $0.1 \mathrm{ml}$ of methanolic extracts was added to $0.3 \mathrm{ml}$ sodium nitrite (5\%) and incubated for $5 \mathrm{~min}$ at room temperature, then $0.3 \mathrm{ml} 10 \%$ (w/v) $\mathrm{AlCl} 3$ and $2 \mathrm{ml} 1 \mathrm{~N} \mathrm{NaOH}$ was added and the total volume was made up to $5 \mathrm{ml}$ with distilled water [19]. The absorbance was measured at $510 \mathrm{~nm}$ by using visible spectrophotometer (Novaspec II Visiblespectro, Japan) at $510 \mathrm{~nm}$. The results were expressed as mg rutin equivalents/g DW.

\section{Fatty acid profile determination}

The total fatty acids of the leaves were extracted according to the method of Folch et al. [20] with some modifications as described by Ebrahimi et al. [21], using chloroforms: methanol 2:1 (v/v) which contained butylated hydroxy toluene to prevent the oxidation during fatty acid extraction. Extracted fatty acids Trans methylated to the fatty acid methyl esters (FAME) using $\mathrm{KOH}$ in methanol and $14 \%$ boron trifluoride $\left(\mathrm{BF}_{3}\right)$ in methanol. The FAME were separated using gas liquid chromatography (Agilent 7890A), using a Supelco SP 2560 capillary column of $100 \mathrm{~m} \times 0.25 \mathrm{~mm}$ ID $\times 0.2 \mu \mathrm{m}$ film thickness (Supelco, Inc., Bellefonte, PA, USA). One microliter was injected into the gas chromatography, equipped with an injector and a flame ionization detector. The nitrogen was the carrier gas at a flow rate of $1.2 \mathrm{ml} / \mathrm{min}$. The split ratio was $1: 10$. The temperature of the injector was $250^{\circ} \mathrm{C}$ and the detector temperature was $270^{\circ} \mathrm{C}$. The column temperature program started runs at $150^{\circ} \mathrm{C}$, for $2 \mathrm{~min}$, warmed to $158^{\circ} \mathrm{C}$ at $1^{\circ} \mathrm{C} / \mathrm{min}$, held for $28 \mathrm{~min}$, warmed to $220^{\circ} \mathrm{C}$ at $1^{\circ} \mathrm{C} / \mathrm{min}$, and then held for $20 \mathrm{~min}$. A reference standard (C4-C24 methyl esters; Sigma-Aldrich, Inc., St. Louis, Missouri, USA), was used to determine correction factors for the determination of individual fatty acid composition. The data are expressed as g/100 $\mathrm{g}$ of detecting total identified fatty acids.

\section{Anti-oxidant activity assay}

\section{Nitric oxide (NO) scavenging activity}

The nitric oxide (NO) scavenging activity of each plant extract was determined by the method of Tsai et al. [22]. Vitamin C, BHT and $\alpha$-tocopherol were used as controls. The NO scavenging activity was calculated according to the formula: $[(\mathrm{A} 0-\mathrm{A} 1) / \mathrm{A} 0] \times 100 \%$; where $\mathrm{A} 0$ was the absorbance of the control reaction and A1 was the absorbance in the presence of the sample.

\section{$A B T S$ radical cation-scavenging}

The ABTS was evaluated by Giao et al. [23] method. ABTS was dissolved in water, to a $7 \mathrm{~mm}$ concentration. ABTS radical cation (ABTS. ${ }^{+}$) was produced by reacting ABTS stock solution with $2.45 \mathrm{mM} \mathrm{K} \mathrm{K}_{2} \mathrm{O}_{8}$ and allowing the mixture to stand at room temperature (dark place) overnight before utilization.

\section{Anti-bacterial activity assay}

The antibacterial assay of the leaf extracts of three varieties of L. pumila was carried out by the disc diffusion method as described by Boussaada et al. [24] against Staphylococcus aureus S1431, Escherichia coli E256, Pseudomonas aeruginosa PI96, Micrococcus luteus, Klibsiella pneumonia K36, Bacillus subtilis B145, Bacillus cereus $\mathrm{B} 43$ and Enterococcus aeruginosa. All the bacteria were purchased from the Institute of Malaysian Research (IMR) and maintained in the department of Microbiology, Faculty of Biotechnology and Biomolecular Sciences, Universiti Putra Malaysia. In this assay, the positive control without extracts (solvent) and reference control used kanamycin as the standard antibiotic agent. The extracts inhibitions were corrected based on positive control values. The experiments were run in triplicate.

\section{Statistical analysis}

All data are presented as means $( \pm$ SEM) of at least three replicates $(n=3)$. The total phenolic and flavonoid contents, fatty acid, anti-oxidant and anti-bacterial properties were analyzed using analysis of variance (ANOVA) with the Statistical Analysis System (SAS) Version 9.1 (SAS Institute, Cary, NC). Significant differences among means from triplicate analyses $(\mathrm{p}<0.05)$ were determined by Duncan's Multiple Range Test. The level of significance was set at $\mathrm{p}<0.05$ for all statistical tests.

\section{Competing interests}

The authors declare that they have no competing interests.

\section{Authors' contributions}

Study design and experimental work was by Dr. EK under the supervision of Prof. HZJ. The antioxidant activity and anti-bacterial analysis have been done by Dr. EK and AG. GC and bioactive compounds have carried out by Dr. ME and Dr. EK. All authors reviewed and approved the final version. 


\section{Acknowledgements}

The authors would like to thank the Ministry of Higher Education Malaysia, and the Research Management Centre, Universiti Putra Malaysia (UPM) for sponsoring this work. Authors also wish to acknowledge the support given by the Faculty of Agriculture, and the Faculty of Biotechnology and Biomolecular Sciences, University Putra Malaysia in terms of laboratory facilities.

\section{Author details}

${ }^{1}$ Department of Crop Science, Faculty of Agriculture, Universiti Putra Malaysia, 43400 Serdang, Selangor, Malaysia. ${ }^{2}$ Department of Veterinary Preclinical Sciences, Faculty of Veterinary Medicine, 43400 Serdang, Selangor, Malaysia.

Received: 23 October 2014 Accepted: 6 January 2015

Published: 23 January 2015

\section{References}

1. Oskoueian E, Abdullah N, Hendra R, Karimi E. Bioactive compounds, antioxidant, xanthine oxidase inhibitory, tyrosinase inhibitory and antiinflammatory activities of selected agro-industrial by-products. Int J Mol Sci. 2011;12(12):8610-25.

2. Karimi E, Jaafar HZE, Ahmad S. Antifungal, anti-inflammatory and cytotoxicity activities of three varieties of Labisia pumila benth. from microwave obtained extracts. BMC Complement Altern Med. 2013:13(20):1-10.

3. Desbois AP, Smith VJ. Antibacterial free fatty acids: activities, mechanisms of action and biotechnological potential. Appl Microbiol Biotechnol. 2010;85 (6):1629-42.

4. Wille JJ, Kydonieus A. Palmitoleic acid isomer (C16:1 $\triangle 6)$ in human skin sebum is effective against Gram-positive bacteria. Skin Pharmacol Appl Skin Physiol. 2003;16:176-87.

5. McGaw $\amalg$, Jäger $A K$, van Staden J. Antibacterial effects of fatty acids and related compounds from plants. S Afr J Bot. 2002;68:417-23.

6. Yff BTS, Lindsey KL, Taylor MB, Erasmus DG, Jäger AK. The pharmacological screening of Pentanisia prunelloides and the isolation of the antibacterial compound palmitic acid. J Ethnopharmacol. 2002;79:101-7.

7. Namdeo AG. Plant cell elicitation for production of secondary metabolites: A review. Pharmacognosy Rev. 2007;1:69-79.

8. Jaafar HZE, Mohamed Haris NB, Rahmat A. Accumulation and partitioning of total phenols in two varieties of Labisia pumila Benth. under manipulation of greenhouse irradiance. Acta Hort. 2008;797:387-92.

9. Ibrahim $\mathrm{MH}$, Jaafar HZE. The relationship of nitrogen and $\mathrm{C} / \mathrm{N}$ on secondary metabolites and antioxidant activities in three varieties of Malaysia Kacip Fatimah (Labisia pumila Blume). Molecules. 2011;16:5514-26.

10. Sofowora A. Research on medicinal plants and traditional medicine in Africa. J Altern Complement Med. 1996;2:365-72.

11. Wang YC, Chuang Y, Hsu H. The flavonoid, carotenoid and pectin content in peels of citrus cultivated in Taiwan. Food Chem. 2008;106:277-84.

12. Basile A, Giordano S, Lopez-Saez JA, Cobianchi RC. Antibacterial activity of pure flavonoids isolated from mosses. Phytochemistry. 1999;52:1479-82.

13. Rauha J, Remes S, Heinonen M, Hopia A, Kahkonen M, Kujala T, et al. Antimicrobial effects of Finnish plant extracts containing flavonoids and other phenolic compounds. Int J Food Microbiol. 2000:56:3-12.

14. Panizzi L, Caponi C, Catalano S, Cioni P, Morelli I. In vitro antimicrobial activity of extracts and isolated constituents of Rubus ulmifolius. J Ethnopharmacol. 2002;79:165-8.

15. Hayes ML, Berkovitz BK. The reduction of fissure caries in Wistar rats by a soluble salt of nonanoinic acid. Arch Oral Biol. 1979;24:663-6.

16. Kabara JJ, Swieczkowski DM, Conley AJ, Truant JP. Fatty acids and derivatives as antimicrobial agents. Antimicrob Agents Chemother. 1972:2:23-8.

17. Gordaliza M. Natural products as leads to anticancer drugs. Clin Transl Oncol. 2007:9(12):767-76.

18. Xiao WH, Han LJ, Shi B. Microwave-assisted extraction of flavonoids from Radix Astragali. Sep Purif Technol. 2008;62:614-8.

19. Ismail HI, Chan KW, Mariod AA, Ismail M. Phenolic content and antioxidant activity of cantaloupe (cucumismelo) methanolic extracts. Food Chem. 2010;119:643-7.

20. Folch J, Lees M, Sloane Stanley GH. A simple method for the isolationand purification of total lipides from animal tissues. J Biol Chem. 1975:1:497-509.
21. Ebrahimi M, Rajion MA, Goh YM, Sazili AQ, Schonewille JT. Effect of linseed oil dietary supplementation on fatty acid composition and gene expression in adipose tissue of growing goats. Biomed Res Int. 2013;2013:1-11.

22. Tsai PJ, Tsai TH, Yu CH, Ho SC. Comparison of NO-scavenging and NOsuppressing activities of different herbal teas with those of green tea. Food Chem. 2007;103:181-7.

23. Giao MS, Gonzalez-Sanjose ML, Rivero-Perez MD, Pereira Cl, Pintado ME, Malcata FX. Infusions of Portuguese medicinal plants: Dependence of final antioxidant capacity and phenolic content on extraction features. J Sci Food Agr. 2007;87:2638-47.

24. Boussaada O, Chriaa J, Nabli R, Ammar S, Saidana D, Mahjoub MA, et al. Antimicrobial and antioxidant activities of methanol extracts of Evax pygmaea (Asteraceae) growing wild in Tunisia. World J Microbiol Biotechnol. 2008;24:1289-96

doi:10.1186/0717-6287-48-9

Cite this article as: Karimi et al.: Fatty acid composition, antioxidant and antibacterial properties of the microwave aqueous extract of three varieties of Labisia pumila Benth. Biological Research 2015 48:9.

\section{Submit your next manuscript to BioMed Central and take full advantage of:}

- Convenient online submission

- Thorough peer review

- No space constraints or color figure charges

- Immediate publication on acceptance

- Inclusion in PubMed, CAS, Scopus and Google Scholar

- Research which is freely available for redistribution

Submit your manuscript at www.biomedcentral.com/submit 